\title{
Sustainability as a Matrix of Experiential Marketing
}

\author{
Angela Dettori ${ }^{1}$ \\ ${ }^{1}$ Department of Economics and Business Science, University of Cagliari, Italy \\ Correspondence: Angela Dettori, Department of Economics and Business Science, University of Cagliari, Italy. \\ E-mail: angela.dettori@unica.it
}

Received: April 12, 2019 Accepted: May 6, 2019 Online Published: May 21, 2019

doi:10.5539/ijms.v11n2p29 URL: https://doi.org/10.5539/ijms.v11n2p29

\begin{abstract}
Recent years have highlighted a significant increase in the relevance of environmental protection and sustainability to consumers, firms, and society as a whole. Taking this new situation into account, most organizations are aware of this change and wish to be seen as taking steps to improve behaviors in this regard. This challenge requires managers to make wise strategic choices and for organizations to be more flexible in adapting to changes in the economy, in the environment and in the "whims" of consumers. The aim of the present study is to examine the potential role of sustainability as a matrix of experiential marketing to understand how a memorable, emotional and responsible connection between consumer and sustainable brand can generate customer loyalty and affect the purchase decision. Taking a case study approach, this study analyzes an ecological campaign called "The Fun Theory", contributing to strengthening this new theory, according to which "fun" is the best way to change the bad habits of people in responsible and sustainable manner.
\end{abstract}

Keywords: sustainability, experiential marketing, "The Fun Theory"

\section{Introduction}

A firm, a society or an ecosystem can be characterized as sustainable only when it expresses the ability to keep itself in time. To achieve this result, not only is economic equilibrium necessary, but also it is necessary to take into account the social and environmental aspects of activities. Thus, a process of transformation of companies' business models towards more sustainable paradigms (Belz \& Peattie, 2012) is inevitable. In the past, this process could be defined as a strategic choice, but today, it is also a mandatory condition for survival in the market (Keller, 2003). This situation implies a rethinking of all organizational functions, particularly marketing, therefore, starting from these considerations, the aim of this study is to understand if:

Are managers aware of their customers' increasing propensity towards sustainability? How are they preparing themselves to answer this challenge?

Because conventional marketing is considered mainly responsible for continuously stimulating consumers to increase consumption, the goal of sustainable marketing is to promote sustainable consumer behavior. The ability of businesses to successfully use sustainable marketing in support of their strategy to obtain sustainability depends on economic, social and environmental sensitivity and also on the ability to enhance experience (Sheth \& Parvatiyar, 1995). In recent years, there has been an increase in interest in building and enhancing customer experience among researchers and practitioners.

Schmitt (1999a) assures us that, currently, experience is one of the "hottest" movements in business practice and defines experiential marketing (Schmitt, 1999b) as a new approach that treats consumption as a total experiment by taking cognizance of the rational and emotional aspects of consumption using eclectic methods.

Brakus et al. (2009), instead, conceptualize the brand experience as sensations, feelings, cognitions and behavioral responses evoked by brand-related stimuli that are part of a brand's design and identity, packaging, communications and environments (Brakus, Schmitt, Berned, \& Zarantonello, 2009). However, the brand experience (Zarantonello, Schmitt, \& Brakus, 2007; Schmitt, 2009) binds a sustainable and responsible behavior that adds value to the experience, allowing recipients to undergo unconsciously sustainable experiences.

A new trend in marketing that allows living "original" experience is called "Gamification" (Hamari, 2013). Gamification can help companies to develop a mindset oriented to the market and improve the job satisfaction of employees and customers through fun. Some scholars (Lucassen \& Jansen, 2014) have defined this practice as 
the use of the elements of fun in marketing and particularly in relationship marketing; however, other scholars (Huber \& Hilty, 2015) have emphasized the processes that transform leisure, habits and customs in a way that can obtain and provide experiences of sustainable value.

This paper is organized as follows. After the introduction, a literature review on experiential and sustainable marketing and an analysis of the concept of gamification as a realization of games and its rise in the market are presented. The next section explains how gamification is used by businesses and the manner in which it may constitute a powerful motivational lever that can have positive effects for more sustainable directions. To better highlight this concept, a case study of a company that dynamically uses gamification is examined. Finally, concluding remarks and implications for managerial practice are discussed.

\section{Literature Review}

\subsection{Experiential Marketing}

Traditional marketing strategies that focus on price or quality are no longer a source of differentiation and competitive advantage. Scholars advocate that one of the main routes to successful differentiation and competitive advantage is a much stronger focus on the customer (Same \& Larimo, 2012).

Experiential marketing has evolved as the dominant marketing tool of the future. Companies have moved away from traditional "features and benefits" marketing towards creating experiences for their customers (Yeh, Chen, $\&$ Chen, 2019).

Customer satisfaction is a key outcome of experiential marketing and is defined as the "customer fulfillment response", which is an evaluation and an emotion-based response to a service (Yuan \& Wu, 2008). It is an indication of the customer's belief in the probability or possibility of a service's leading to a positive feeling. This favorable affect is positively and negatively related to satisfaction and involves the marketing of a product or service through experience. Experience is a personal occurrence with emotional significance created by an interaction with product or brand related stimuli (Österle, Kuhn, \& Henseler, 2018).

Schmitt (2003) distinguishes between five types of experience that marketers can create for customers, including sensory experience (sensing), affective experience (feeling), creative cognitive experience (thinking), physical experience, behaviors and lifestyles (acting), and social-identity experience, all relating to a reference group or culture (relating). The author posits that the ultimate goal of experiential marketing is to create a holistic experience that seeks to integrate all of these individual types of experiences into a total customer experience.

The concept of "experience marketing" also offers engaging, interactive, and entertaining brand experiences (Brakus, Schmitt, Berned, \& Zarantonello, 2009). The idea is to communicate the essence of a brand through personal experience.

However, there is no consensus today on what the term "experience marketing" refers to and the context in which it is used. Lee, Hsiao and Yang (2010) assert that experience marketing aims to induce marketing staff to emphasize the overall experience quality for consumers conveyed by brands, including rational decision-making and sentimental consumption experience. Yeh, Chen and Chen (2019) define experience marketing as "the creation of a memorable episode based on a customer's direct personal participation or observation". However, they simultaneously use the exact same definition for experiential marketing.

Experiences offer human beings the chance to feel, think, act, relate, and promote sustainability. Sustainable experiences are a dynamic, innovative way to respect the environment, to improve social life and to have a deeper understanding of people's lives, leading to better marketing decisions.

\subsection{Sustainable Marketing}

Sustainable marketing is "a management conception which attends to the environmental and social demands and eventually turns them into competitive advantages by delivering customers value and satisfaction" (Belz \& Karstens, 2010, p. 3). A wide view of sustainable marketing regards it as the adoption of sustainable business practices that create better businesses, better relationships and a better world (Tseng, Wu, Chiu, Lim, \& Tan, 2018).

Other scholars (Belz, 2008; Belz \& Peattie, 2009; 2012) have attempted to explain the thin line that constitutes the difference between "sustainable" and "sustainability marketing". They explain that the word "sustainable" is related to something that is durable or long lasting and, "sustainable marketing is a kind of marketing, which builds long lasting customer relationships effectively, without any particular reference to sustainable development or consideration of sustainability issues" (Belz, 2008, p. 120), whereas "sustainability marketing is more explicitly related to sustainable development agenda" and defined as "building and maintaining sustainable 
relationships with customers, the social environment and the natural environment" (Belz \& Peattie, 2009, p. 110).

Regarding the field of business, the ability of businesses to successfully use sustainable marketing in support of their strategy to obtain sustainability depends on their social and environmental sensitivity. Belz and Karstens (2010) state that there are certain distinguishing features of the sustainable marketing paradigm.

Environmental and social issues are the easiest to identify. In traditional marketing, the environmental and social aspects of products are hardly considered, and green marketing (Mintu \& Lozada, 1993; Polonsky, 2001) only includes ecological problems.

Another particular problem is the identification of the intersection of social and environmental problems with consumer behavior (Peattie \& Belz, 2010). This identification is a crucial aspect of sustainability and sustainable marketing, which simultaneously attempt to find solutions to social and environmental problems and meet customer demands (Belz \& Peattie, 2012).

The central role of communication, which must create both a vision and an experience concerning sustainable values such as clean air, green technology, waste, energy savings, etc., also provides a good development of sustainable marketing; in sum, the communication of experiences leads people to act more responsibly (Tromp, Hekkert, \& Verbeek, 2011).

The appropriate communication for sustainable change has a participatory character, and today, new tools for sustainable development, such as fun, are emerging. Indeed, recent studies (O'Brien, 2012) have shown that communicating an experience through fun can be the best way to change the bad habits of people.

\subsection{A New Trend: "Gamification"}

In the academic literature, the idea that, through doing fun things, people are more likely to change behavior is called "gamification". According to Zichermann and Linder, this idea constitutes one of the core concepts of business and strategy: "without employee and customer engagement, the best laid strategies and tactics are doomed to fail" (Zichermann \& Linder, 2010, p. 16).

There are two main definitions, one definition that refers to the use of game thinking and game mechanics to engage users and solve problems and another definition that concerns the use of game elements and game design techniques in non-game contexts (Lucassen \& Jansen, 2014).

Both definitions highlight that this new trend requires the use of game mechanics, game elements or game design techniques.

One of the main things to highlight about gamification is that can be used in non-game contexts, e.g., with firms, making effective behaviors and fun into business applications (Suh \& Wagner, 2017). Gamification has gained popularity in recent years because organizations have become aware that traditional incentive structures for motivating employees and customers no longer work and gamification represents a method that can successfully replace the old approaches. Through gamification, businesses can move away from extrinsic motivators, such as monetary rewards, towards intrinsic motivators (Suh \& Wagner, 2017). In doing so, gamified applications and businesses can positively drive engagement, interaction, collaboration, awareness and learning by combining fun and happiness.

Sustainability is not immune to the growing proliferation of gamification as a way to encourage desired behaviors through the allure of competition, rewards and fun. Cities, business organizations and product manufacturers, among others, have begun creating such games and incentives to meet their goals to be more sustainable (Zichermann \& Linder, 2010).

Gamification is not all fun and games. It is important for organizations to clearly identify their goals, understand the motivation they are seeking to tap into and develop intrinsic and extrinsic rewards that encourage long-term behavioral changes.

\section{Methodology}

The case study is the preferred research method for examining complex social phenomena because it allows researchers to develop a holistic understanding of real-life events (Eisenhardt \& Graebner, 2007; Yin, 2009; 2012). This methodology is particularly well-suited to developing an analysis through providing a deep comprehension of the empirical phenomena and the context in which they occur.

The present study considers an ecological campaign called "The Fun Theory", launched by a Stockholm-based advertising agency and promoted by Volkswagen. According to "The Fun Theory", fun is the best way to change 
the bad habits of people. This theory, in essence, is based on the same concept as gamification: by making things fun, people are more likely to change (Zichermann \& Linder, 2010).

Several sources were used to collect data that were useful to building the case study. First, extensive archival work, including the collection of relevant articles, was conducted. Second, the manner in which Volkswagen promoted "The Fun Theory" was analyzed, highlighting the numerous ecological campaigns that oriented people towards sustainable behavior.

Indeed, this case study begins by analyzing how things as simple as fun and happiness are the easiest way to change people's behavior for the better, for the environment, for organizations and for society. As Aristotle argued, "What we have to do, we learn by doing", which is the exact approach to life experiences.

\section{Case Study}

Experience marketing offers the opportunity to change routine transactions into powerful events that demonstrate the value of a business.

An effective example of experiential marketing was provided by "The Fun Theory" promoted by Volkswagen. The overall concept was to engage people to invent creative ways to make everyday activities more fun. Over 700 people submitted different ideas to make routine activities, such as recycling, picking up trash and going to the gym, more enjoyable. These ideas were collected by a Stockholm-based advertising agency (DDB), which created successful and effective viral videos to show how "green" behaviors can be fun. Only in the last ten years or so have companies begun to harness the marketing power of what is known as the viral video-a video that becomes popular through internet sharing, typically through media sharing sites such as YouTube.

Humor is oftentimes a vital component to making these videos catchy. Whether the videos provide humor, wit, surprise, or sheer entertainment, the key to their success is their voluntary and rapid distribution across a wide variety of Internet circuits, generating thousands of views.

"The Fun Theory" video seems to have hit the nail on the head and, surprisingly, not through humor or shock value but rather through the sheer uniqueness of taking everyday mundane behaviors and making them fun.

In each experiment, the test is to see whether people will alter their simple, everyday behaviors to be more environmentally friendly if such behaviors are made to be more fun. One of the videos documents "The Fun Theory" as it is tested on a staircase in a Stockholm subway station that was converted into working piano keys in an attempt to convince commuters to take the stairs instead of the escalator. Another test uses sound effects to make the proper disposal of trash a cartoon-like experience. The idea is intriguing, and the results are even more so: apparently, turning a set of subway stairs into a real-life piano makes people $66 \%$ more likely to use it, and more than $60 \%$ of people throw waste in the sounding bin. For this reason, the videos are highly entertaining, and their Internet circulation has soared, with some videos having accrued over a million hits on YouTube.

The positive reactions to these "being-green-made-easy" videos cause us to forget that they are actually part of a campaign. No wonder this occurs, given that viral videos take their name from "viral marketing", which is also known as "word-of-mouth" or "stealth" marketing: the videos are shared, and the marketing occurs on its own. In "The Fun Theory" videos, Volkswagen's brand placement is as subtle as possible, with a simple VW logo that appears at the end of each video. Yet, with the videos spreading across the Internet like wildfire, the logo makes an understated yet collectively powerful impression on consumers.

These videos make their way among hundreds of thousands of viewers, and positive associations with the VW brand accompany them. Despite the fact that these videos do not market the VW car by promoting its performance and its virtues of efficiency but instead launch new green experiential initiatives, these videos sound like the definition of a perfect brand experience.

Some key takeaways from this experience marketing campaign can be summarized:

Surprise: This experience marketing event was clearly a surprise to each person who walked in the park or to each commuter coming out of the train station. It broke them out of their normal routine and created a unique and memorable experience. Look for ways to brighten the clients' day that will take them by surprise.

Document the fun: The team that created the sounding waste bin or the stairs also installed multiple cameras to document the reactions of people who experienced the fun of throwing away their trash or climbing the piano keys. When you create an experience marketing event, give special thought to how you are going to record the fun. Video, photos and testimonials are golden content marketing opportunities that extend the impact of what could be a single-day event.

Create shareable content: The total time for each video is approximately one minute. This is an ideal length for 
social media users to share this content on their networks. The videos continue to pop up on Facebook on a regular basis. Facebook has also made sharing interesting content doable in two simple clicks. This ease in shareability increases the chances that smart content will reach beyond your network.

Open up to crowdsourcing: The theme of the campaign was "the thought that something as simple as fun is the easiest way to change people's behavior for the better". Look for ways to open up the experience marketing idea through contests, comments and other social features.

Consider a soft sell: The videos only made a brief mention of Volkswagen at the end of each video. Taking a conservative approach to overt branding boosted the shareability of the video because it did not feel like a sales pitch; associating the brand with moments of happiness in peoples' lives will make more of an impact than a standard features-and-benefits sales presentation.

The case study shows that, in this advertising campaign, the consumer enables the marketing process in more ways than one. People like to undergo experiences, specifically fun experiences, and adopting a marketing strategy based on fun experiences can be a way to educate people to be sustainable in a fun and experiential manner.

The Fun Theory is based on the idea that something as simple as fun is the easiest way to change people's behavior for the better. We apply this thinking to every environmentally friendly innovation we make. It should never have to be a compromise to help the planet. Moreover, we believe more people will act responsibly, and drive greener, if they have fun on the way (The Fun Theory, 2014).

\section{Conceptual Model}

Experience, as defined within the realm of management, is a personal occurrence with emotional significance created by an interaction with product- or brand-related stimuli (Same \& Larimo, 2012).

For marketing to become experiential, the marketing activities must create "something extremely significant and unforgettable for the consumer immersed in the experience" (Caru \& Cova, 2003, p. 273).

A well-designed experience engages the attention and emotion of the consumer, becomes memorable and allows for a free interpretation because it is non-partisan (Hoch, 2002). In contrast to traditional marketing, which focuses on obtaining customer satisfaction, experiential marketing creates emotional attachment for consumers (McCole, 2004).

The sensory or emotional element of a total experience has a greater impact on shaping consumer preferences than the product or service attributes (Zaltman, 2003). The benefits of a positive experience include the value it provides the consumer (Babin, Darden, \& Griffin, 1994; Darden \& Barbin, 1994; Holbrook, 1999) and the potential for building customer loyalty (Pine \& Gilmore, 1999; Gobe \& Zyman, 2001).

Starting from these considerations and the numerous conceptual models proposed (Csikszentmihalyi, 1997; Wood \& Masterman, 2007; Leppiman \& Same, 2011) for the formation of experience marketing, this work proposes a model with the goal of developing the relationship between sustainability, experiential marketing and "The Fun Theory" as high-impact emotional elements.

The proposed conceptual model (see Figure 1.) shows a process of interaction between sustainability, "The Fun Theory" and experiential marketing, creating a stimulus and a change in consumer behavior. It is essential to understand that a product/service or a brand is not inherently experiential and may constitute merely positive stimuli. In turn, "The Fun Theory" may have an effect on behavior and purchase decisions through fun and indirectly lead consumers to make more responsible choices.

Several experiments (The Fun Theory, 2014) demonstrate that "fun" appears to be the best way to change human behavior for the better, so what better way to tie this theory to a company or brand?

Experience creates value for both consumers and firms, and it represents a significant relationship between the perceptual activity of a person and his or her life situations (Leppiman \& Same 2011).

Thus, experience as an economic offering is a relevant, meaningful relationship, facilitating communication between the company, brand, service and consumers. That is what the consumer is experiencing in life situations that create meaningful and fun relationships. All this is connected to the reference context (environmental, economic, social), emphasizing the interaction between business and the environment and the strong sustainable orientation for businesses and consumers in general.

Schmitt also states that experiences are private events that occur in response to some stimulation (1999a; 1999b). By selecting the ExPros (Schmitt, 1999a; 1999b), marketers can also provide stimuli that result in fun 
experiences for consumers. The fun is a positive stimulus linked to a brand that can change the life experiences of the consumer.

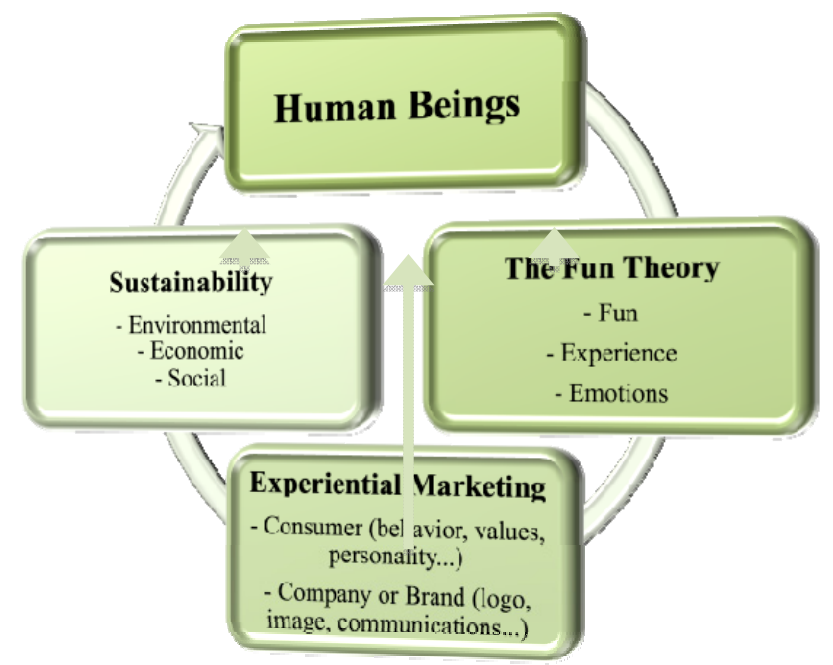

Figure 1. Conceptual model

\section{Conclusions}

From the analysis of the case study, it clearly emerges that there are different benefits to implementing an experiential marketing strategy, e.g., creating an emotional connection, developing positive perceptions, and gaining credibility; and when all this is combined with fun, firms obtain even more advantageous results.

The conceptual model proposed creates a strong interaction between the company and the consumer through "fun experiences" that lead people to act in a more responsible and sustainable manner.

The creation of this model integrates aspects that have become more and more essential today for the development and success of a firm. In other words, the implementation of experiential marketing strategies that adopt "The Fun Theory" must integrate and balance all three dimensions of sustainability in a responsible manner.

Focusing on delivering experiences is an ideal way to develop relationships and bonds that enable brands to grow over time and create a strong sustainable orientation for consumers.

Managers are aware of both the important role of experiences and the propensity of customers towards sustainability, but they must think to communicate easily and effectively. Communication campaigns are too elaborate, and people today need simple and immediate actions. The case study presented in this work applies simple and immediate actions, "fun", to create a strong competitive advantage for the firm and to make consumers more responsible. These results constitute the answers to the following research questions: "Are managers aware of their customers' increasing propensity towards sustainability?" "How are they preparing themselves to answer to this challenge?"

Today, people are in search of meaning, happiness, fun, sense, new forms of fulfillment and core values, which they often find in market offerings (Fortezza \& Pencarelli, 2011). To be successful, Poulsson and Kale (2004) also argue that experiential marketing should have personal relevance for the customer, offer an element of surprise and engender learning, as shown by the case study examined.

\section{Further Research}

This paper seeks to understand whether the sustainability can be a matrix of experiential marketing and to explain the relationships between them.

The connection between "experience" and "sustainability" is taking its first steps, and "The Fun Theory", which is an emerging theory, represents only a first application of this connection. For this reason, there is little empirical research in the field, the relationships between the terms have not yet been studied and new conceptual models must be tested.

It is necessary to continue studying the relationship between the two concepts more thoroughly through content 
analysis and also to analyze the terms to better understand the relationships between them. This work proposes a qualitative research methodology with a case study and creates a conceptual model to finalize "The Fun Theory" and to yield a rich understanding of the phenomenon. Finally, the further development and application of the proposed conceptual model by firms is also necessary.

\section{Managerial Implications}

The success of companies derives from their abilities to embrace and deliver emotionally engaging customer experiences or transform customers by guiding them through experiences (Pine \& Gilmore, 1999).

Creative experience marketing, when applied correctly, leads to a greater impact for the customer and increased effectiveness and is also very useful as a differentiation strategy.

The proposed model and the case study should assist marketing professionals and scholars in understanding the importance of relationships between these concepts and exploring this bond (between experience and sustainability), which has been little studied in the academic literature.

Marketing managers should also perform observational research to monitor what people do when they have an experience and conduct survey-based research to examine the meaning and value of an experience to obtain relevant input for designing effective marketing strategies.

\section{References}

Babin, B. J., Darden, W. R., \& Griffin, M. (1994). Work and or fun-measuring hedonic and utilitarian shopping value. Journal of Consumer Research, 20(4), 644-656. https://doi.org/10.1086/209376

Belz, F. M. (2008). Marketing in the age of sustainable development. In A. Tukker et al. (Eds.), System Innovation for Sustainability 1. Perspectives on Radical Changes to Sustainable Consumption and Production (pp. 114-135). Greenleaf: Sheffield.

Belz, F. M., \& Karstens, B. (2010). Strategic and Instrumental Sustainability Marketing in the Western European Food Processing Industry: Conceptual Framework and Hypothesis. Paper presented in the Corporate Responsibility Research Conference, Euromed Management School Marseille, France.

Belz, F. M., \& Peattie, K. (2009). Sustainability Marketing Management: a Global Perspective (pp. 101-122). Wiley: Cheltenham.

Belz, F. M., \& Peattie, K. (2012). Sustainability Marketing: A Global Perspective (2nd ed.). Wiley: Cheltenham.

Brakus, J. J., Schmitt, B. H., \& Zarantonello, L. (2009). Brand Experience: What is It? How do We Measure It? And Does It Affect Loyalty? Journal of Marketing, 73(3), 52-68. https://doi.org/10.1509/jmkg.73.3.52

Carù, A., \& Cova, B. (2003). Revisiting consumption experience: A more humble but complete view of the concept. Marketing Theory, 3(2), 267-286. https://doi.org/10.1177/14705931030032004

Csikzentmihalyi, M. (1997). Finding Flow. New York, NY: Perseus Book.

Darden, W. R., \& Babin, B. J (1994). Exploring the concept of the affective quality: Expanding the concept of retail personality. Journal of Business Research, 29(2), 101-109. https://doi.org/10.1016/0148-2963(94)90014-0

Eisenhardt, K. M., \& Graebner, M. E. (2007). Theory building from cases: opportunities and challenges. Academy of Management Journal, 50(1), 25-32. https://doi.org/10.5465/amj.2007.24160888

Fortezza, F., \& Pencarelli, T. (2011). Experience marketing: specific features and trends. The Wish Days case study. Journal of Marketing Trends, 1(6), 57-69.

Gobe, M., \& Zyman, S. (2001). Emotional Branding: The New Paradigm for Connecting Brands to People. New York, NY: Allworth Press.

Hamari, J. (2013). Transforming Homo Economicus into Homo Ludens: A Field Experiment on Gamification in a Utilitarian Peer-To-Peer Trading Service. Electronic Commerce Research and Applications, 12(4), 236-245. https://doi.org/10.1016/j.elerap.2013.01.004

Hoch, S. J. (2002). Product experience is seductive. Journal of Consumer Research, 29(3), 448-454. https://doi.org/10.1086/344422

Holbrook, M. B. (1999). Consumer Value. A Framework for Analysis and Research. London and New York: Routledge.

Huber, M. Z., \& Hilty, L. M. (2015). Gamification and Sustainable Consumption: Overcoming the Limitations of 
Persuasive Technologies. In L. M. Hilty \& B. Aebischer (Eds.), ICT Innovation for Sustainability (pp. 367-385). Springer International Publisching. https://doi.org/10.1007/978-3-319-09228-7_22

Keller, K. L. (2003). Strategic Brand Management. Building, Measurement and Managing Brand Equity. New Jersey: Pratice Hall.

Lee, M. S., Hsiao, H. D., \& Yang, M. F. (2010). The study of the relationships among experiential marketing, service quality, customer satisfaction and customer loyalty. The International Journal of Organizational Innovation, 3(2), 353-379.

Leppiman, A., \& Same, S. (2011). Experience marketing: conceptual insights and the difference from experiential marketing. In G. Prause \& U. Venesaar (Eds.), Regional Business and Socio-Economic Develop- ment 5: University-Business Cooperation (pp. 240-258). Berliner Wissenschafts-Verlag.

Lucassen, G., \& Jansen, S. (2014). Gamification in Consumer Marketing-Future or Fallacy? Social and Behavioral Sciences, 148, 194-202. https://doi.org/10.1016/j.sbspro.2014.07.034

McCole, P. (2004). Refocusing marketing to reflect practice: The changing role of marketing for business. Marketing Intelligence and Planning, 22(5), 531-539. https://doi.org/10.1108/02634500410551914

Mintu, A. T., \& Lozada, R. H. (1993). Green Marketing Education. A Call for Action. Marketing Education Review, 3(3), 17-23. https://doi.org/10.1080/10528008.1993.11488420

O'Brien, C. (2012). Sustainable Happiness and Well-Being: Future Directions for Positive Psychology. Psychology, 3(12), 1196-1201. https://doi.org/10.4236/psych.2012.312A177

Österle, B., Kuhn, M. M., \& Henseler, J. (2018). Brand worlds: Introducing experiential marketing to B2B branding. Industrial Marketing Management, 72, 71-98. https://doi.org/10.1016/j.indmarman.2018.04.015

Peattie, K., \& Belz, F. (2010). Sustainability marketing-An innovative conception of marketing. Marketing Review of St. Gallen, 27(5), 8-15. https://doi.org/10.1007/s11621-010-0085-7

Pine, B. J., \& Gilmore, J. H. (1999). The Experience Economy: Work Theatre is and Every Business is a Stage. Massachusetts, Harvard Business School Press.

Polonsky, M. J. (2001). Re-evaluating Green marketing: A Strategic Approach. Business Horizon, 44(5), 21-30. https://doi.org/10.1016/S0007-6813(01)80057-4

Poulsson, S. H. G., \& Kale, S. H. (2004). The Experience Economy and Commercial Experiences. The Marketing Review, 4(3), 267-277. https://doi.org/10.1362/1469347042223445

Same, S., \& Larimo, J. (2012). Marketing Theory: Experience Marketing and Experiential Marketing. 7th International Scientific Conference, Business and Management 2012, May 10-11, Vilnius, LITHUANIA. https://doi.org/10.3846/bm.2012.063

Schmitt, B. (1999a). Experiential marketing: How to get customers to sense, feel, think, act and relate to your company and brands. New York, NY: Free Press.

Schmitt, B. (1999b). Experiential Marketing. Journal of Marketing Management, 15(1-3), 53-67. https://doi.org/10.1362/026725799784870496

Schmitt, B. (2003). Customer Experience Management: A Revolutionary Approach to Connecting with Your Customers. Hoboken, New Jersey: John Wiley \& Sons.

Schmitt, B. (2009). The concept of brand experience. Journal of Brand Management, 16(7), 417-419. https://doi.org/10.1057/bm.2009.5

Sheth, J. N., \& Parvatiyar, A. (1995). Ecological Imperatives and the Role of Marketing. In M J. Polonsky \& A. Mintu-Wimsatt (Eds.), Environmental Marketing: Strategies, Practice, Theory, and Research (pp. 3-20). New York: The Haworth Press.

Suh, A., \& Wagner, C. (2017). How gamification of an enterprise collaboration system increases knowledge contribution: an affordance approach. Journal of Knowledge Management, 21(2), 416-431. https://doi.org/10.1108/JKM-10-2016-0429

The Fun Theory. (2014). Retrieved from https://goodvertising.site/the-fun-theory/

Tromp N., Hekkert, P., \& Verbeek, P. P. (2011). Design for Socially Responsible Behavior: A Classification of Influence Based on Intended User Experience. Design Issue, 27(3), 3-19. https://doi.org/10.1162/DESI_a_00087 
Tseng, M. L., Wu, K. J., Chiu, A. S. F., Lim, M. K., \& Tan, K. (2018). Service innovation in sustainable product service systems: Improving performance under linguistic preferences. International Journal of Production Economics, 203, 414-425. https://doi.org/10.1016/j.ijpe.2018.07.020

Wood, E. H., \& Masterman, G. (2007). Event Marketing: Measuring an experience? 7th International Marketing Trends Congress, Jan 17-19.

Yeh, T. S., Chen, S. H., \& Chen, T. F. (2019). The Relationships among Experiential Marketing, Service Innovation, and Customer Satisfaction-A Case Study of Tourism Factories in Taiwan. Sustainability, 11(4), 1-12. https://doi.org/10.3390/su11041041

Yin, R. K. (2009). Case Study Research. Design and methods. Thousand Oaks: Sage.

Yin, R. K. (2012). Applications of case study research (3rd ed.). Thousand Oaks CA: Sage.

Yuan, Y. H. E., \& Wu, C. K. (2008). Relationship among experiential marketing, experiental value, and customer satisfaction. Journal of Hospitality \& Tourism Research, 32(3), 387-410. https//doi.org/10.1177/1096348008317392

Zaltman, G. (2003). How Consumers Think: Essential Insights into the Mind of the Market. Boston, MA: Harvard Business School Press.

Zarantonello, L., Schmitt, B. H., \& Brakus, J. J. (2007). Development of the Brand Experience Scale. Advances in Consumer Research, 34, 580-582.

Zichermann, G., \& Linder, J. (2010). Game-based-marketing: inspire customer loyalty through rewards challenges and contests. New Jersey: Jon Wiley \& Sons Inc. Hoboken.

\section{Copyrights}

Copyright for this article is retained by the author, with first publication rights granted to the journal.

This is an open-access article distributed under the terms and conditions of the Creative Commons Attribution license (http://creativecommons.org/licenses/by/4.0/). 